\title{
Effects of Varied Nitrogen Supply and Irrigation Methods on Distribution and Dynamics of Soil $\mathrm{NO}_{3}-\mathrm{N}$ during Maize Season
}

\author{
Dongliang $\mathrm{Qi}^{1,2} \&$ Tiantian $\mathrm{Hu}^{1,2}$ \\ ${ }^{1}$ College of Water Resources and Architectural Engineering, Northwest A\&F University, Yangling, China \\ ${ }^{2}$ Key Laboratory of Agricultural Soil and Water Engineering in Arid and Semiarid Areas of Ministry of Education, \\ Northwest A\&F University, Yangling, China \\ Correspondence: Tiantian $\mathrm{Hu}$, College of Water Resources and Architectural Engineering, Northwest A\&F \\ University, Weihui Road 23, Yangling 712100, China. Tel: 86-29-8708-2902. E-mail: hutiant@nwsuaf.edu.cn
}

Received: September 27, $2016 \quad$ Accepted: October 27, $2016 \quad$ Online Published: December 15, 2016

doi:10.5539/jas.v9n1p1 URL: http://dx.doi.org/10.5539/jas.v9n1p1

The research is financed by the Special Fund for Agro-scientific Research in the Public Interest (201503124), National Natural Science Fund of China (51079124) and the National High Technology Research and Development Program of China (2011AA100504).

\begin{abstract}
A field experiment was carried out to investigate the effects of different supply methods of nitrogen (N) fertilizer and irrigation on the spatial distribution and dynamics of soil $\mathrm{NO}_{3}-\mathrm{N}$ for maize (Zea mays L.) grown in northwest China in 2012 and 2014. In 2012, there were three irrigation methods: alternate furrow irrigation (AI), fixed furrow irrigation (FI) and conventional furrow irrigation (CI). Three N supply methods: alternate N supply (AN), fixed $\mathrm{N}$ supply (FN) and conventional $\mathrm{N}$ supply $(\mathrm{CN})$, were applied at each irrigation method. In 2014, the fixed treatments were excluded. Soil $\mathrm{NO}_{3}-\mathrm{N}$ in horizontal direction was measured to $100 \mathrm{~cm}$ soil profile. For 2012, at filling stage, compared to $\mathrm{CI}$, AI increased soil $\mathrm{NO}_{3}-\mathrm{N}$ concentration under the plant by 4.5 to $7.4 \%$ in $0-40 \mathrm{~cm}$ soil profile and decreased that by 9.9 to $14.4 \%$ in $40-80 \mathrm{~cm}$ for three $\mathrm{N}$ supply methods. $\mathrm{NO}_{3}-\mathrm{N}$ concentration between two sides of the ridge was comparable for $\mathrm{AN}$ and $\mathrm{CN}$ coupled with $\mathrm{AI}$ or $\mathrm{CI}$. When compared to $\mathrm{CI}$, AI reduced soil $\mathrm{NO}_{3}-\mathrm{N}$ concentration in $60-100 \mathrm{~cm}$ by 4.8 to $8.7 \%$ from 12 collars stage to maturity over different positions when coupled with $\mathrm{CN}$. Soil residual $\mathrm{NO}_{3}-\mathrm{N}$ at maturity in $0-100 \mathrm{~cm}$ was the lowest in AI coupled with $\mathrm{CN}$ or AN. The 2014 experiment verified the above results. Therefore, alternate furrow irrigation coupled with conventional or alternate $\mathrm{N}$ supply brought an optimum spatial distribution of soil $\mathrm{NO}_{3}-\mathrm{N}$ during maize season, resulting in little soil residual $\mathrm{NO}_{3}-\mathrm{N}$ at maturity.
\end{abstract}

Keywords: soil $\mathrm{NO}_{3}-\mathrm{N}$ distribution, soil $\mathrm{NO}_{3}-\mathrm{N}$ dynamics, nitrogen supply method, irrigation method, soil residual $\mathrm{NO}_{3}-\mathrm{N}$, Zea mays

\section{Introduction}

Declining freshwater resources have stimulated research into developing novel irrigation strategies to increase crop water use efficiency (Morison, Baker, Mullineaux, \& Davies, 2008). Partial root-zone irrigation (PRI) is a new strategy of deficit irrigation. PRI can be applied in two ways: alternate PRI and fixed PRI. In alternate PRI, half of the root zone is irrigated while the other half is dried, and then the previously well-watered side of the root system is allowed to dry while the previously dried side is fully irrigated (Kang, Zhang, Liang, Hu, \& Cai, 1997). However, in fixed PRI, a fixed half of the root zone is always irrigated while the other half is always dried. Alternate PRI is considered a water-saving irrigation technique and is being intensively studied on field crops (Kang, Liang, Hu, \& Zhang, 1998; Tang, Li, \& Zhang, 2010; Shahnazari, Liu, Anderson, Jacobesen, \& Jensen, 2007).

Soil nitrate $\left(\mathrm{NO}_{3}-\mathrm{N}\right)$ is the dominated nitrogen $(\mathrm{N})$ form in dryland soil. Its sustainable supply in root zone has predominant effect on crop yield and $\mathrm{N}$ fertilizer use. In a large part, low $\mathrm{N}$ use efficiency is attributed to potential $\mathrm{NO}_{3}-\mathrm{N}$ leaching and residual $\mathrm{NO}_{3}-\mathrm{N}$ at harvest. Studies have demonstrated that residual $\mathrm{NO}_{3}-\mathrm{N}$ (Tarkalson, Payero, Ensley, \& Shaprio, 2006; Wang, F. Li, Zhang, G. Li, \& Vance, 2012) as well as N leaching (Tafteh \& Sepaskhah, 2012; Zotarelli et al., 2009) increased as N fertilizer application rates were higher. It is 
fully understood that $\mathrm{N}$ and water have a huge interaction and irrigation significantly affects $\mathrm{N}$ status in soil. Excess application of water resulted in $\mathrm{NO}_{3}-\mathrm{N}$ leaching (Ju, Liu, Zhang, \& Roelcke, 2004; Gheysari, Mirlatifi, Homaee, Asddi, \& Hoogenboom, 2009). Furthermore, compared to conventional furrow irrigation (CI) and fertilization, separation of $\mathrm{N}$ fertilizer and water with alternate PRI increased $\mathrm{NO}_{3}-\mathrm{N}$ in the upper soil layers $(0-60 \mathrm{~cm})$ by 30 to $60 \%$, while reduced that in the deeper soil layers $(60-200 \mathrm{~cm}$ ) by 13 to $33 \%$ (Han et al., 2014) Placement of $\mathrm{N}$ fertilizer in the ridge rather than the furrow could lower $\mathrm{N}$ leaching in fixed PRI or CI (Benjamin, Havis, Ahuja, \& Alonso, 1994; Benjamin, Poter, Duke, \& Alnoso, 1997), so did placement of N fertilizer in non-irrigated rather than irrigated furrow in fixed PRI (Zhu et al., 2013). These suggest that potential residual and leaching of $\mathrm{NO}_{3}-\mathrm{N}$ in soil not only depends on the rates of $\mathrm{N}$ and water, but also on $\mathrm{N}$ and water placement in soil profile.

The position of $\mathrm{NO}_{3}-\mathrm{N}$ in soil profile, determining soil $\mathrm{N}$ leaching and residual, varies largely during the growing season. Besides $\mathrm{N}$ source and the application rate, distribution and dynamics of $\mathrm{NO}_{3}-\mathrm{N}$ in soil depends on the volume and placement of irrigation water in the active root zone. Because $\mathrm{NO}_{3}-\mathrm{N}$ tended to accumulate towards the boundary of the wetted volume (Bar-Yosef \& Sheikholslami, 1976; Li, Zhang, \& Ren, 2003), the use of irrigation strategies that limit the wetted volume in the root zone may change $\mathrm{NO}_{3}-\mathrm{N}$ distribution and improve $\mathrm{N}$ use efficiency (NUE) (Singandhupe, Rao, Patil, \& Brahmanand, 2003). In furrow irrigation, a symmetrical distribution of $\mathrm{NO}_{3}-\mathrm{N}$ across the ridge was found in both alternate PRI and $\mathrm{CI}$, but $\mathrm{NO}_{3}-\mathrm{N}$ concentration in the non-irrigated furrow was higher than that in the irrigated one under fixed PRI (Liu, Zhang, Yang, Wang, \& Li, 2011). Alternate PRI could promote upward movement of $\mathrm{NO}_{3}-\mathrm{N}$ within a deeper soil layer when compared to $\mathrm{CI}$ (Wang et al., 2014). Placement of $\mathrm{N}$ fertilizer to the non-irrigated rather than irrigated furrow under alternate PRI was favored for maintaining distribution of $\mathrm{NO}_{3}-\mathrm{N}$ more at the upper soil profile $(0-40 \mathrm{~cm})$ for a longer time (Xing, Wang, L. Li, \& S. Li, 2003). Nevertheless, these researches on the distribution and dynamics of $\mathrm{NO}_{3}-\mathrm{N}$ under PRI were mainly conducted in a pot (Wang et al., 2014) or a semi-arid area (Xing et al., 2003; Liu et al., 2011). Moreover, the effect of $\mathrm{N}$ application patterns on changing $\mathrm{NO}_{3}-\mathrm{N}$ under PRI has not been considered.

Thus, this study was conducted for maize production in an arid area of northwest China to investigate how distribution and dynamics of $\mathrm{NO}_{3}-\mathrm{N}$ is influenced by different $\mathrm{N}$ supply and irrigation methods.

\section{Materials and Methods}

\subsection{Experimental Site}

A field study was conducted during the 2012 and the 2014 growing seasons at Wuwei Experimental Station for Efficient Use of Crop Water, Ministry of Agriculture, northwest China (latitude $37^{\circ} 52^{\prime} 20^{\prime \prime} \mathrm{N}$, longitude $102^{\circ} 50^{\prime} 50^{\prime \prime} \mathrm{E}$, altitude $1581 \mathrm{~m}$ ). The site is in a typical continental temperate climate zone with mean annual precipitation of $164.4 \mathrm{~mm}$, mean annual evapotranspiration of $2000 \mathrm{~mm}$. Mean annual sunshine duration is over $3000 \mathrm{~h}$ and mean annual temperature is $8.8^{\circ} \mathrm{C}$. The groundwater level is consistently $25-30 \mathrm{~m}$ below the soil surface. The soil is a light sandy loam. Total precipitation in the growing season was $129 \mathrm{~mm}$ in 2012 and 174 $\mathrm{mm}$ in 2014 (Figure 1). In the top soil layer $\left(0-40 \mathrm{~cm}\right.$ ), organic matter is $15.90 \mathrm{~g} \mathrm{~kg}^{-1}$, total $\mathrm{N}$ is $0.85 \mathrm{~g} \mathrm{~kg}^{-1}$, total phosphorus is $0.93 \mathrm{~g} \mathrm{~kg}^{-1}$, available phosphorus is $6.22 \mathrm{mg} \mathrm{kg}^{-1}$, and available potassium is $236.24 \mathrm{mg} \mathrm{kg}^{-1}$. 


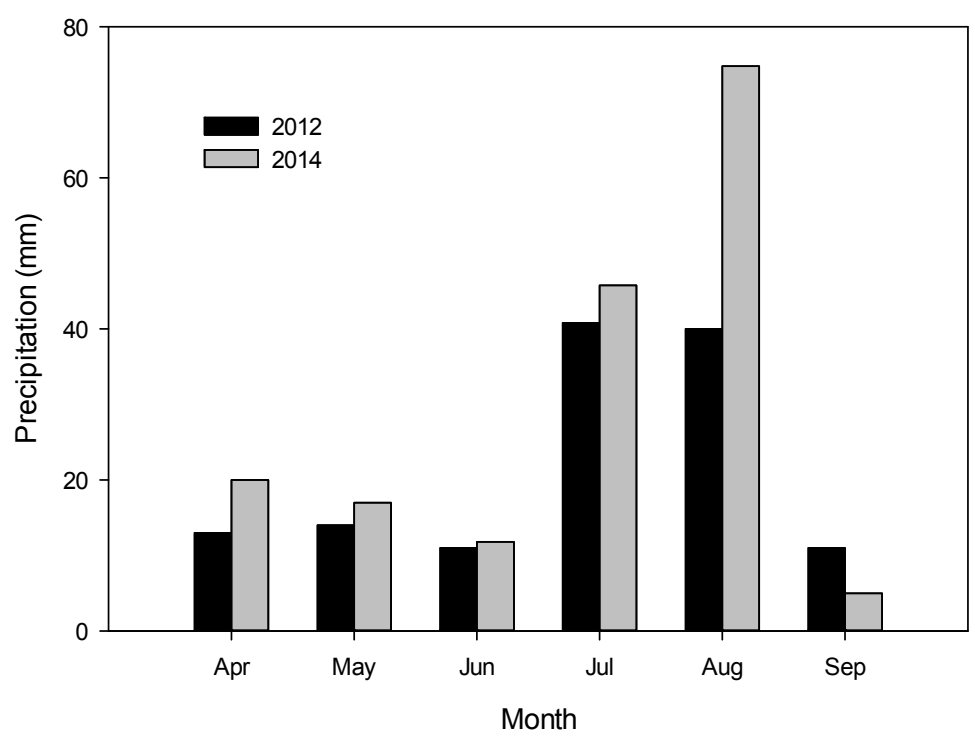

Figure 1. Monthly precipitation during the growth period at the experimental site in 2012 and 2014

\subsection{Crop Management}

Furrow irrigation was adopted in the field experiment. A trapezoid fracture surface was established for furrows and ridges. Furrows were $30 \mathrm{~cm}$ in depth and $20 \mathrm{~cm}$ in width at bottom. Ridges were $20 \mathrm{~cm}$ and $35 \mathrm{~cm}$ in width at top and bottom, respectively. This resulted in a ridge spacing of $55 \mathrm{~cm}$. All experimental ridges were built in a west-east direction. Superphosphate fertilizer was applied at $77 \mathrm{~kg} \mathrm{ha}^{-1}$ one day before furrows were established. Ridges were then covered using plastic film. Each plot was $24 \mathrm{~m}^{2}(4 \mathrm{~m} \times 6 \mathrm{~m})$ in 2012 and $(4 \mathrm{~m} \times 8 \mathrm{~m}) 32 \mathrm{~m}^{2}$ in 2014. Seven ridges were established for each plot in each year. Grain maize, cultivar 'Golden northwest No. 22' (Zea mays L.) were sown in the ridges at a density of 73000 plants ha ${ }^{-1}$ on April 19 and 20 in 2012 and 2014, respectively. Crop was harvested on September 20 and 22 in 2012 and 2014, respectively.

\subsection{Experimental Design}

The experiment factors were irrigation method and $\mathrm{N}$ fertilizer supply method. In 2012, irrigation methods included conventional furrow irrigation (CI), alternate furrow irrigation (AI) and fixed furrow irrigation (FI). CI means that all furrows were irrigated for every irrigation event. AI means that one of the two neighboring furrows was alternately irrigated during consecutive watering. FI means that irrigation was fixed to one of the two neighboring furrows. $\mathrm{N}$ supply methods included conventional $\mathrm{N}$ supply $(\mathrm{CN})$, alternate $\mathrm{N}$ supply $(\mathrm{AN})$ and fixed $\mathrm{N}$ supply (FN). $\mathrm{CN}$ means that $\mathrm{N}$ fertilizer was applied to all furrows. AN means that $\mathrm{N}$ fertilizer was alternately applied to one of the neighboring two furrows in consecutive fertilization. $\mathrm{FN}$ means that $\mathrm{N}$ fertilizer was fixed to one of every two furrows. This experimental plan yielded 9 treatments, i.e. CIAN, CICN, CIFN, AIAN, AICN, AIFN, FIAN, FICN and FIFN. In addition, FIFN was conducted in two ways, named FIFNS (application of N fertilizer to the irrigated furrow under FI) and FIFND (application of $\mathrm{N}$ fertilizer to the non-irrigated furrow under FI), respectively.

In 2014, based on the results of 2012, fixed treatments (FI and FN) were excluded, and only the AIAN, AICN, CIAN and CICN treatments were conducted. All treatments were arranged in a randomized block design with three replicates in two years.

Twice as much water and/or $\mathrm{N}$ was applied to the irrigated/fertilized furrow in AI/AN and FI/FN as that to the furrow in $\mathrm{CI} / \mathrm{CN}$ treatment, so that the total amount of water and/or $\mathrm{N}$ was the same for all treatments. Urea was applied at a rate of $200 \mathrm{~kg} \mathrm{~N} \mathrm{ha}^{-1}$ to the center of the furrows in $5 \mathrm{~cm}$ deep, which is the optimum $\mathrm{N}$ rate for maize production in local area (Yang \& Su, 2009). $\mathrm{N}$ fertilizer application included basal application (50\%) and topdressing at 12 collars (25\%) and tasseling (25\%). According to Zhang, Ma, and E (2007), irrigation was applied after planting and at the 6 collars, 12 collars, tasseling and filling stages of maize ( $75 \mathrm{~mm}$ per time), respectively. The growth stage of maize was determined according to Ritchie and Hanway (1982). The irrigation water was supplied by a pipe with a diameter of $55 \mathrm{~mm}$, and the amount of water applied was measured with a 
water meter installed at the discharging end of the pipe. Irrigation and $\mathrm{N}$ fertilizer topdressing was conducted on the same day. The position details of localized irrigation and $\mathrm{N}$ application are described in Table 1.

Table 1. Time and position of localized irrigation and nitrogen $(\mathrm{N})$ fertilization

\begin{tabular}{llllll}
\hline Items & Seeding & 6 collars & 12 collars & Tasseling & Filling \\
\hline DAP of & $3(2012)$ & 45 & 84 & 98 & 119 \\
irrigation (d) & $3(2014)$ & 45 & 82 & 96 & 115 \\
Location of AI & Both furrows & South furrow & North furrow & South furrow & North furrow \\
Location of FI & Both furrows & South furrow & South furrow & South furrow & South furrow \\
Location of CI & Both furrows & Both furrows & Both furrows & Both furrows & Both furrows \\
DAP of N & $-1(2012)$ & $/$ & 84 & 98 & $/$ \\
application (d) & $-1(2014)$ & $/$ & 82 & 96 & $/$ \\
Location of AN & South furrow & $/$ & North furrow & South furrow & $/$ \\
Location of FN & South furrow & $/$ & South furrow & South furrow & $/$ \\
& North furrow ${ }^{\text {a }}$ & $/$ & North furrow ${ }^{\text {a }}$ & North furrow & $/$ \\
Location of CN & Both furrows & $/$ & Both furrows & Both furrows & $/$ \\
\hline
\end{tabular}

Note. "/" represents no treatment. DAP, days after planting; AI, alternate furrow irrigation; CI, conventional furrow irrigation; FI, fixed furrow irrigation; $\mathrm{AN}$, alternate nitrogen supply; $\mathrm{CN}$, conventional nitrogen supply; FN, fixed nitrogen supply. Fixed N/water treatments were only conducted in 2012. ${ }^{a}$ represents N supplied only for FIFND treatment. FIFNS and FIFND treatments denote application of $\mathrm{N}$ fertilizer to the irrigated (south) and non-irrigated (north) furrow under FI, respectively.

\subsection{Soil Sampling and Measurement}

Soil samples for $\mathrm{NO}_{3}-\mathrm{N}$ measurement were taken from each plot before experiment and at 6 collars, 12 collars, tasseling, filling and maturity growth stages, which corresponds to $-2,44,82,97,117$ and 152 days after planting (DAP) in 2012, and -2, 43, 80, 94, 113 and 149 DAP in 2014, respectively. These sampling dates were earlier than corresponds fertilization/irrigation dates. Three plants in the middle row in each plot were randomly chosen for soil sampling position during 6 collars to maturity. Before sampling, shoots were cut near the soil surface. A hand-driven auger with $7 \mathrm{~cm}$ diameter was used for sampling. The sampling was collected to $100 \mathrm{~cm}$ depth from three positions around one plant. The three positions were: (1) directly over the crown of the plant; (2) south and (3) north side of the plant. For position (2) and (3), sampling sites were positioned one quarter of row spacing directly opposite the crown. The core was sectioned into $20 \mathrm{~cm}$ depths and a $10-15 \mathrm{~g}$ sample was used for soil $\mathrm{NO}_{3}-\mathrm{N}$ concentration determination.

$\mathrm{NO}_{3}-\mathrm{N}$ was determined using a Flow Solution IV Analyzer (FSIV, O.I. Analytical, U.S.A.) after extraction with a 1:5 ratio (w/w) soil: $1 \mathrm{~mol} \mathrm{~L}^{-1} \mathrm{KCl}$ solution (Bao, 2000). The amount of $\mathrm{NO}_{3}-\mathrm{N}\left(\mathrm{kg} \mathrm{N}^{-1}{ }^{-1}\right)$ stored in $0-100 \mathrm{~cm}$ soil profile at harvest was calculated according to the equation modified by Emteryd (1989):

$$
Y_{i}=T_{i} \times B D_{i} \times\left[\mathrm{NO}_{3}\right]_{i} \times 0.1
$$

Where, $T_{i}$ is the thickness of soil layer in $\mathrm{cm} ; B D_{i}$ is the bulk density in $\mathrm{g} \mathrm{cm}^{-3}, 1.32,1.40,1.55,1.58$ and $1.60 \mathrm{~g}$ $\mathrm{cm}^{-3}$ for soil layer of 0-20, 20-40, 40-60, 60-80, 80-100 cm, respectively (Liu, $\mathrm{Li}, \mathrm{Pan}, \mathrm{Qu}, \& \mathrm{Du}, 2009$ ); [ $\left.\mathrm{NO}_{3}\right]_{i}$ is the soil $\mathrm{NO}_{3}-\mathrm{N}$ concentration in $\mathrm{mg} \mathrm{kg}^{-1}$, which was the mean $\mathrm{NO}_{3}-\mathrm{N}$ concentration across the different positions, and 0.1 is the conversion coefficient.

\subsection{Statistical Aanalysis}

To compare $\mathrm{NO}_{3}-\mathrm{N}$ concentration and residual $\mathrm{NO}_{3}-\mathrm{N}$ amount among treatments, analysis of variance (ANOVA) was performed using the general linear model-univariate procedure from SPSS 12.0 software. FIFND treatment was excluded in analysis of ANOVA in 2012, and the means were compared for any significant differences among all treatments using the Duncan's multiple range tests at the significant level of $P=0.05$. Since treatment amount differed among years, ANOVA was performed separately in two years. 


\section{Results}

\subsection{Spatial Distribution of Soil $\mathrm{NO}_{3}-\mathrm{N}$}

In consideration that the last $\mathrm{N}$ fertilization application was at tasseling (VT) stage of maize. Filling $\left(\mathrm{R}_{2}\right)$, which is the next sampling time to follow VT, is one of the pivotal stages for N uptake by maize (Tsai, Huber, Glover, \& Wareen, 1984), $\mathrm{R}_{2}$ was chosen to characterize spatial distribution of $\mathrm{NO}_{3}-\mathrm{N}$.

In 2012, irrigation method, $\mathrm{N}$ supply method, and their interaction had a significant impact on $\mathrm{NO}_{3}-\mathrm{N}$ concentration at three positions of the plant in $0-40 \mathrm{~cm}$ soil profile except for the interaction in $20-40 \mathrm{~cm}$ under the plant (UP). Among them, at the marked significant level, $\mathrm{N}$ supply method influenced $\mathrm{NO}_{3}-\mathrm{N}$ concentration at north of the plant (NP) and south of the plant (SP). Moreover, the significant impact was also observed for N supply method at NP and SP in 40-80 cm, and irrigation method at NP in 40-60 cm and SP in $60-80 \mathrm{~cm}$ (Table 2).

In 2014, a little different result occurred for all the four treatments (Table 2). The irrigation method had a significant impact on $\mathrm{NO}_{3}-\mathrm{N}$ concentration at three positions of the plant in $0-40 \mathrm{~cm}$ soil profile, and the significant impact of irrigation method extended to $40-100 \mathrm{~cm}$ for NP and SP (excluded NP in $80-100 \mathrm{~cm}$ ). A significant impact on $\mathrm{NO}_{3}-\mathrm{N}$ concentration by $\mathrm{N}$ supply method was only observed for NP in $40-60 \mathrm{~cm}$ and $\mathrm{SP}$ in $20-40 \mathrm{~cm}$ (Table 2).

Table 2. Variance analysis for soil $\mathrm{NO}_{3}-\mathrm{N}$ concentration among different treatments at filling stage $\left(\mathrm{R}_{2}\right)$ in 2012 and 2014

\begin{tabular}{|c|c|c|c|c|c|c|c|}
\hline \multirow{2}{*}{ Year } & \multirow{2}{*}{ Position of sampling } & \multirow{2}{*}{ Factors } & \multicolumn{5}{|c|}{ Soil depth $(\mathrm{cm})$} \\
\hline & & & $0-20$ & $20-40$ & $40-60$ & $60-80$ & $80-100$ \\
\hline \multirow[t]{9}{*}{2012} & \multirow[t]{3}{*}{ North of plant } & IM & $*$ & $*$ & $*$ & NS & NS \\
\hline & & NSM & $* *$ & $* *$ & * & * & NS \\
\hline & & $\mathrm{IM} \times \mathrm{NSM}$ & $* *$ & $*$ & NS & NS & NS \\
\hline & \multirow[t]{3}{*}{ South of plant } & IM & $*$ & $*$ & NS & $*$ & NS \\
\hline & & NSM & $* *$ & $* *$ & $*$ & * & NS \\
\hline & & $\mathrm{IM} \times \mathrm{NSM}$ & $* *$ & $*$ & NS & NS & NS \\
\hline & \multirow[t]{3}{*}{ Under the plant } & IM & * & * & NS & NS & NS \\
\hline & & NSM & $*$ & $*$ & NS & NS & NS \\
\hline & & $\mathrm{IM} \times \mathrm{NSM}$ & * & NS & NS & NS & NS \\
\hline \multirow[t]{9}{*}{2014} & \multirow[t]{3}{*}{ North of plant } & $\mathrm{IM}$ & $*$ & $*$ & $*$ & $*^{*--}$ & $\mathrm{NS}$ \\
\hline & & NSM & NS & NS & $*$ & NS & NS \\
\hline & & $\mathrm{IM} \times \mathrm{NSM}$ & NS & NS & NS & NS & NS \\
\hline & \multirow[t]{3}{*}{ South of plant } & IM & $*$ & $*$ & $*$ & $*$ & $*$ \\
\hline & & NSM & NS & $*$ & NS & NS & NS \\
\hline & & $\mathrm{IM} \times \mathrm{NSM}$ & NS & NS & NS & NS & NS \\
\hline & \multirow[t]{3}{*}{ Under the plant } & IM & $*$ & $*$ & NS & NS & NS \\
\hline & & NSM & NS & NS & NS & NS & NS \\
\hline & & $\mathrm{IM} \times \mathrm{NSM}$ & NS & NS & NS & NS & NS \\
\hline
\end{tabular}

Note. ${ }^{*}, *$ means significant at the 0.05 and 0.01 levels, respectively. IM and NSM represent irrigation and nitrogen supply method, respectively. FIFND treatment was excluded in the variance analysis in 2012, symbol of FIFND treatment is shown in Table 1.

In 2012 (Figure 2), in 0-40 cm soil depth, an approximate symmetrical distribution of $\mathrm{NO}_{3}-\mathrm{N}$ across the ridge was observed for AIAN, AICN, CICN and CIAN treatments (Figures 2a, 2b, 2d and 2e). Concentration of $\mathrm{NO}_{3}-\mathrm{N}$ under SP (42 cm at the horizontal direction) was observed for FN treatments in three irrigation methods (Figures 2c, 2f and 2i) except for FIFND treatment (Figure 2j), in which $\mathrm{NO}_{3}-\mathrm{N}$ concentration under SP was 1.4 to 1.8 times higher than that under NP (14 $\mathrm{cm}$ at the horizontal direction). This reversed in FICN and FIFND treatments and the disparity was larger (Figures $2 \mathrm{~h}$ and $2 \mathrm{j}$ ), i.e., $\mathrm{NO}_{3}-\mathrm{N}$ concentration under $\mathrm{SP}$ was much lower than that under NP. In 40-80 cm soil depth, the situation was a little different: under SP, concentration of $\mathrm{NO}_{3}-\mathrm{N}$ 
was observed for FI treatments in three $\mathrm{N}$ supply methods (Figures $2 \mathrm{~g}$, $2 \mathrm{~h}$ and $2 \mathrm{i}$ ) except for FIFND treatment (Figure 2j). Compared to $\mathrm{CI}$, under UP ( $28 \mathrm{~cm}$ at the horizontal direction), $\mathrm{AI}$ increased $\mathrm{NO}_{3}-\mathrm{N}$ concentration in $0-40 \mathrm{~cm}$ soil depth by 4.5 to $7.4 \%(P>0.05)$ and reduced that in $40-80 \mathrm{~cm}$ soil depth by 9.9 to $14.4 \%(P<0.05)$ among different $\mathrm{N}$ supply methods (Figures $2 \mathrm{a}, 2 \mathrm{~b}, 2 \mathrm{c}, 2 \mathrm{~d}, 2 \mathrm{e}$ and $2 \mathrm{f}$ ). In 80-100 cm soil depth, $\mathrm{NO}_{3}-\mathrm{N}$ concentration was comparable among all treatments (about $10 \mathrm{mg} \mathrm{kg}^{-1}$ ). In 2014 (Figure 3), for AIAN, AICN, $\mathrm{CICN}$ and CIAN treatments, spatial distribution of $\mathrm{NO}_{3}-\mathrm{N}$ was similar to that in 2012. Overall, alternate furrow irrigation coupled with conventional $\mathrm{N}$ supply or alternate $\mathrm{N}$ supply not only benefited the uniform distribution of $\mathrm{NO}_{3}-\mathrm{N}$ in the horizontal direction, but also inhibited downward movement of $\mathrm{NO}_{3}-\mathrm{N}$ in the soil profile.

Horizontal position (cm)
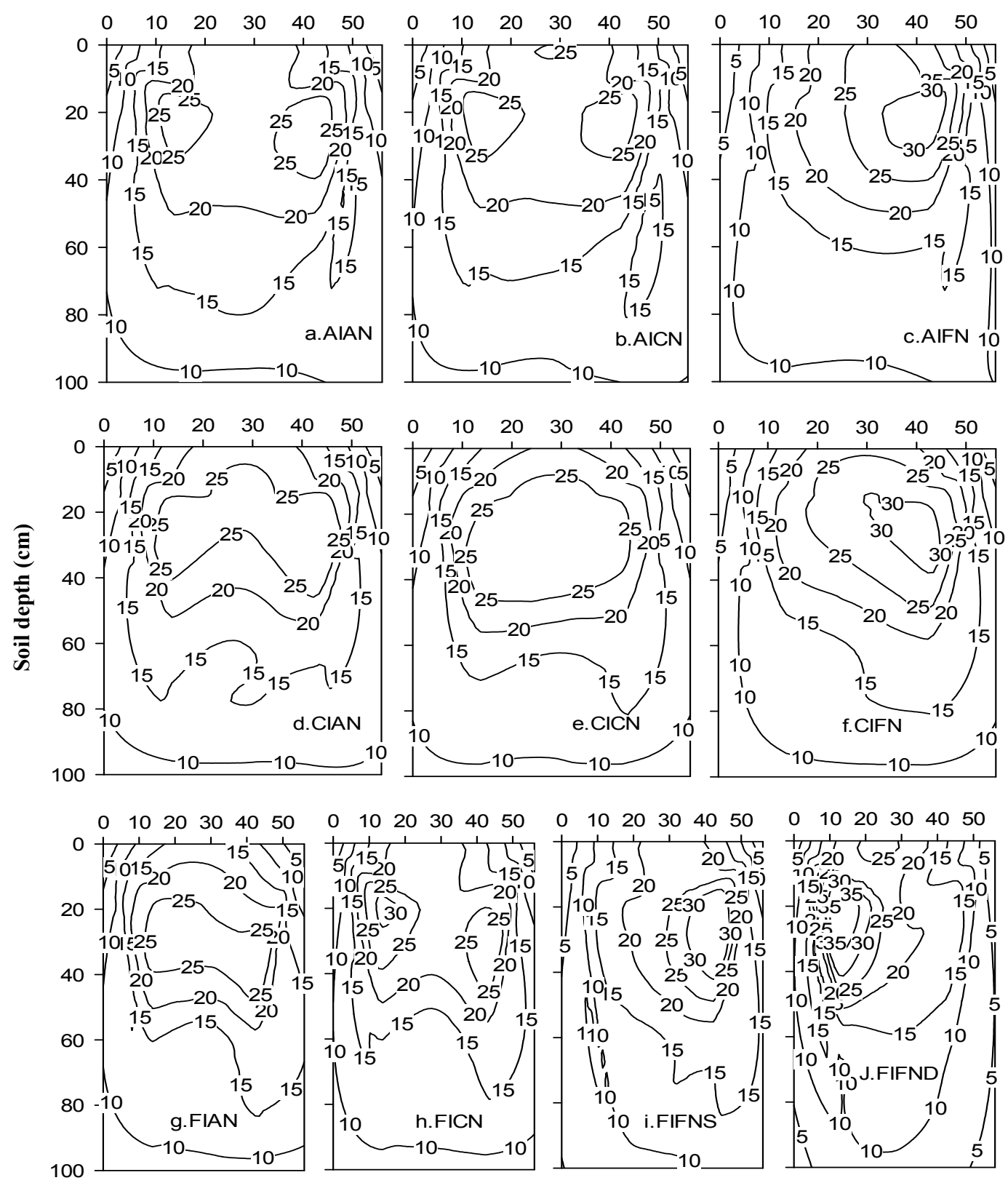

Figure 2. Spatial distribution of soil $\mathrm{NO}_{3}-\mathrm{N}\left(\mathrm{mg} \mathrm{kg}^{-1}\right)$ for different treatments at filling $\left(\mathrm{R}_{2}\right)$ in 2012

Note. 14, 28 and $42 \mathrm{~cm}$ at the horizontal axis represents north, under and south of the plant, respectively. 


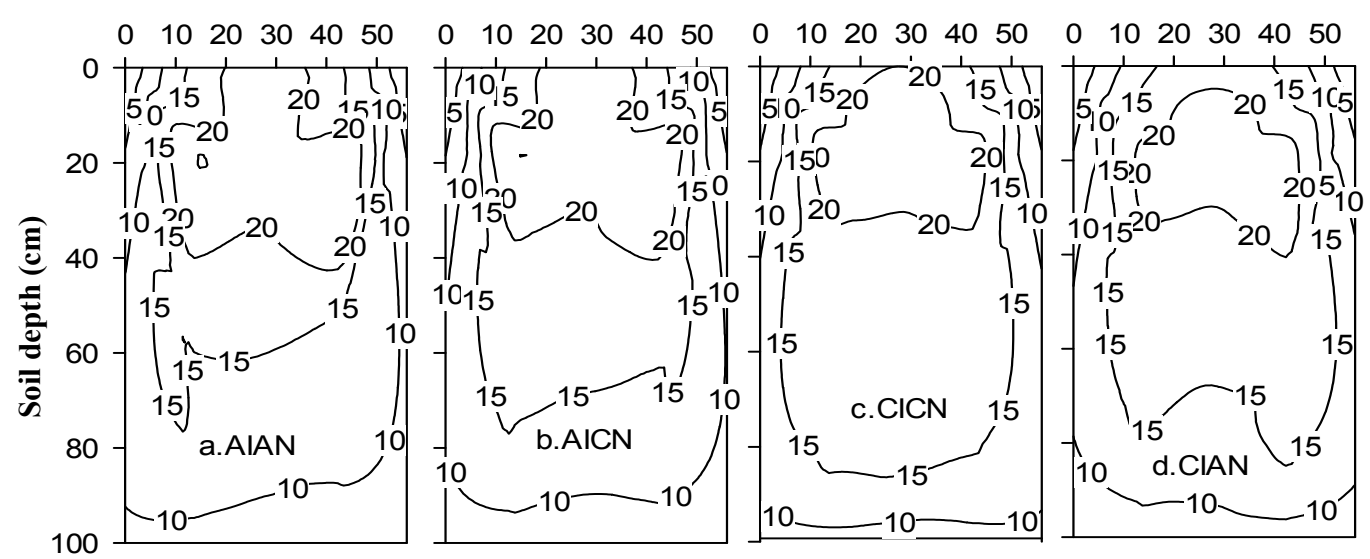

Figure 3. Spatial distribution of soil $\mathrm{NO}_{3}-\mathrm{N}\left(\mathrm{mg} \mathrm{kg}^{-1}\right)$ for different treatments at filling $\left(\mathrm{R}_{2}\right)$ in 2014

Note. 14,28 and $42 \mathrm{~cm}$ at the horizontal axis represents north, under and south of the plant, respectively.

\subsection{Dynamics of Soil $\mathrm{NO}_{3}-\mathrm{N}$ in Different Soil Layers}

The $\mathrm{NO}_{3}$-N dynamics of AICN, CICN, FIFNS and FIFND treatments was shown to reflect several trends of all treatments and avoid too many lines to be unclear at the meantime. Data was pooled if no significant difference was observed among either or both adjacent soil layers and different sampling positions. Over the different sampling positions and soil layers, a similar dynamics of $\mathrm{NO}_{3}-\mathrm{N}$ in the whole growing period occurred in all treatments. Specifically, a significantly increase trend of $\mathrm{NO}_{3}-\mathrm{N}$ concentration was observed from planting to 6 collars $\left(\mathrm{V}_{6}\right)$, slightly decrease from $\mathrm{V}_{6}$ to 12 collars $\left(\mathrm{V}_{12}\right)$, then significantly increase from $\mathrm{V}_{12}$ to $\mathrm{V}_{\mathrm{T}}$, and significantly decrease from $\mathrm{V}_{\mathrm{T}}$ to maturity $\left(\mathrm{R}_{6}\right)$ for all treatments (Figures 4 and 5). Apparently, it displayed a type of ' $\mathrm{M}$ ' for this changing process.

Detailed patterns of changing soil $\mathrm{NO}_{3}-\mathrm{N}$, however, differed among treatments (Figures 4 and 5). In 2012 (Figure 4), after basal $\mathrm{N}$ fertilizer was applied, the increase of $\mathrm{NO}_{3}-\mathrm{N}$ concentration in $0-100 \mathrm{~cm}$ soil profile in SP from planting to $\mathrm{V}_{6}$ was greater in FIFNS while smaller in FIFND treatment than those of the other treatments $(P<$ 0.05). The opposite was true for that $U P$ in $0-40 \mathrm{~cm}$ and NP in $0-60 \mathrm{~cm}$. From $\mathrm{V}_{6}$ to $\mathrm{V}_{12}$, compared to the other treatments, the decrease of $\mathrm{NO}_{3}-\mathrm{N}$ concentration in $0-60 \mathrm{~cm}$ was greater in FIFNS treatment of SP and FIFND treatment of $\mathrm{NP}(P<0.05)$. After $\mathrm{N}$ fertilizer was topdressing at $\mathrm{V}_{12}$, the increase of $\mathrm{NO}_{3}-\mathrm{N}$ concentration in $0-40$ $\mathrm{cm}$ in SP and NP from $\mathrm{V}_{12}$ to VT showed similarities compared to that from planting to $\mathrm{V}_{6}$. However, after N fertilizer was topdressing at $\mathrm{V}_{T}$, no increase of $\mathrm{NO}_{3}-\mathrm{N}$ concentration in $0-100 \mathrm{~cm}$ was observed at $\mathrm{R}_{2}$ (Figure 4). Moreover, compared to the other treatments, the decrease of $\mathrm{NO}_{3}-\mathrm{N}$ concentration in $0-40 \mathrm{~cm}$ from $\mathrm{V}_{\mathrm{T}}$ to $\mathrm{R}_{6}$, was smaller in FIFND treatment of SP and FIFNS treatment of NP $(P<0.05)$. The decrease of $\mathrm{NO}_{3}-\mathrm{N}$ concentration in 40-60 $\mathrm{cm}$ from $\mathrm{V}_{\mathrm{T}}$ to $\mathrm{R}_{2}$ was greater in AICN treatment of SP and FIFND treatment of NP than those of the other treatments $(P<0.05)$. The decrease of $\mathrm{NO}_{3}-\mathrm{N}$ concentration in $40-60 \mathrm{~cm}$ in NP from $\mathrm{R}_{2}$ to $\mathrm{R}_{6}$ was greater in CICN treatment, while that in $60-100 \mathrm{~cm}$ in SP from $\mathrm{R}_{2}$ to $\mathrm{R}_{6}$ was smaller in FIFND treatment than those of the other treatments $(P<0.05)$. In addition, compared to $\mathrm{CICN}$ treatment, AICN treatment reduced the $\mathrm{NO}_{3}-\mathrm{N}$ concentration by 4.8 to $8.7 \%$ in $60-100 \mathrm{~cm}$ from $\mathrm{V}_{12}$ to $\mathrm{R}_{6}$ over the different positions.

In 2014 (Figure 5), compared to CICN treatment, the decrease of $\mathrm{NO}_{3}-\mathrm{N}$ concentration in $0-100 \mathrm{~cm}$ soil profile from VT to $\mathrm{R}_{2}$ was significantly increased by AICN treatment $(P<0.05)$. Compared to CICN treatment, AICN treatment reduced the $\mathrm{NO}_{3}-\mathrm{N}$ concentration by 5.1 to $9.6 \%$ in $60-100 \mathrm{~cm}$ from $\mathrm{V}_{12}$ to $\mathrm{R}_{6}$ over the different positions. Moreover, the dynamics of $\mathrm{NO}_{3}-\mathrm{N}$ concentration of AIAN treatment from $\mathrm{V}_{\mathrm{T}}$ to $\mathrm{R}_{6}$ was comparable to that of AICN in two years (data not shown). 


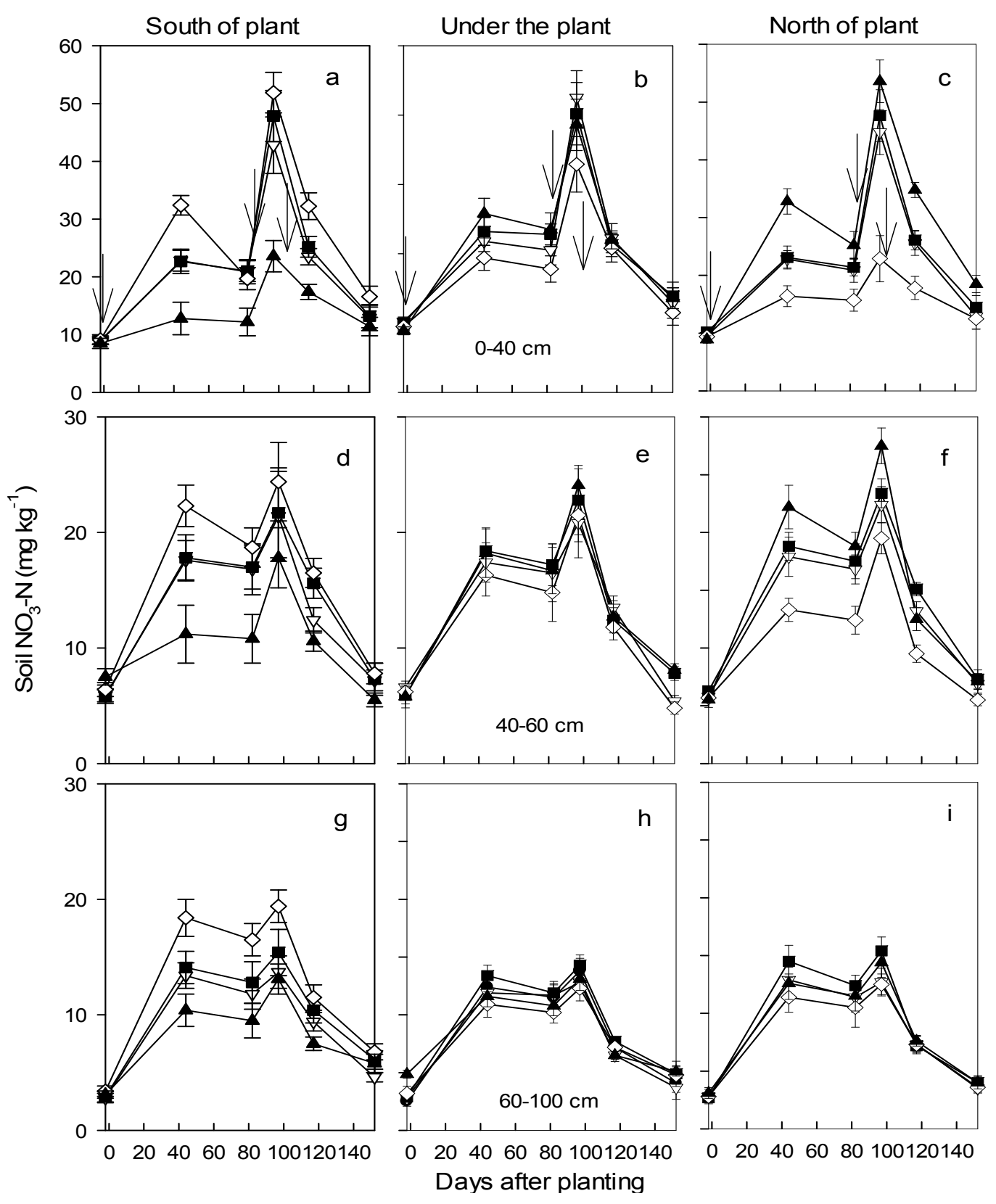

Figure 4. Dynamics of soil $\mathrm{NO}_{3}-\mathrm{N}$ concentration following days after planting at different positions in $0-100 \mathrm{~cm}$ soil layer for AICN, CICN, FIFNS and FIFND treatments in 2012

Note. Symbol of $\mathbf{\square}, \boldsymbol{\Delta}, \nabla$ and $\diamond$ denotes the treatment of CICN, FIFND, AICN and FIFNS, respectively. Arrows represents application of $\mathrm{N}$ fertilizer. Days after planting of -2, 44, 82, 97,117 and $152 \mathrm{~d}$ represents before planting and development stage of maize at 6 collars $\left(\mathrm{V}_{6}\right), 12$ collars $\left(\mathrm{V}_{12}\right)$, tasseling $(\mathrm{VT})$, filling $\left(\mathrm{R}_{2}\right)$ and maturity $\left(\mathrm{R}_{6}\right)$, respectively. 

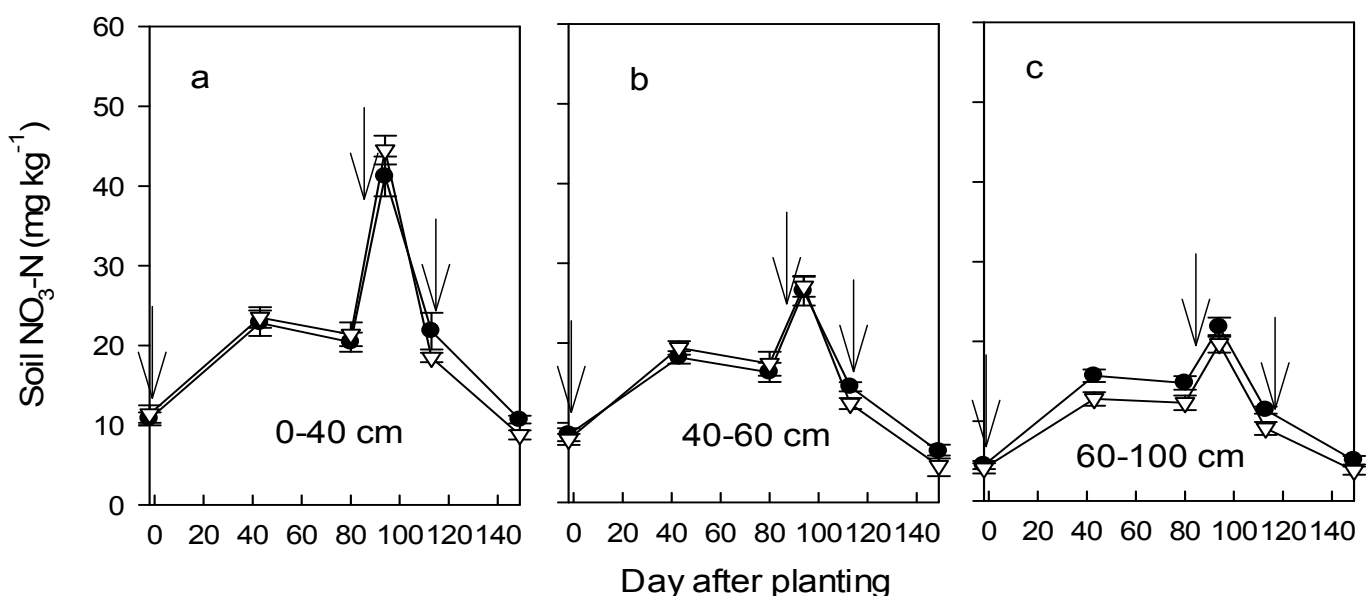

Figure 5. Dynamics of soil $\mathrm{NO}_{3}-\mathrm{N}$ concentration following days after planting in 0-100 cm soil layer for CICN and AICN treatments in 2014

Note. Symbol of $\bullet$ and $\nabla$ denotes the treatment of CICN and AICN, respectively. Data are combined across different positions. Arrows represents application of $\mathrm{N}$ fertilizer. Days after planting of $-2,43,80,94,113$ and $149 \mathrm{~d}$ represents before planting and development stage of maize at 6 collars $\left(\mathrm{V}_{6}\right), 12$ collars $\left(\mathrm{V}_{12}\right)$, tasseling (VT), filling $\left(\mathrm{R}_{2}\right)$ and maturity $\left(\mathrm{R}_{6}\right)$, respectively.

\subsection{Residual Soil $\mathrm{NO}_{3}-\mathrm{N}$}

In 2012 (Table 3), in 0-40 cm soil profile, FIFND had the largest residual $\mathrm{NO}_{3}-\mathrm{N}$ while AIAN and AICN the smallest among the treatments. In $40-60 \mathrm{~cm}$, residual $\mathrm{NO}_{3}-\mathrm{N}$ of both FIFNS and CIFN was significantly higher than that of the other treatments. In $60-80 \mathrm{~cm}$, residual $\mathrm{NO}_{3}-\mathrm{N}$ was the smallest in FIFND treatment. In 80-100 $\mathrm{cm}$, FIFNS treatment had the largest residual $\mathrm{NO}_{3}-\mathrm{N}$ among the treatments. In $0-100 \mathrm{~cm}$ soil profile, compared to $\mathrm{CI}$, residual $\mathrm{NO}_{3}-\mathrm{N}$ was significantly increased by $\mathrm{FI}$ while reduced by $\mathrm{AI}$ in any $\mathrm{N}$ supply method. Compared to $\mathrm{CN}$, residual $\mathrm{NO}_{3}-\mathrm{N}$ of $\mathrm{AN}$ was comparable while that of $\mathrm{FN}$ increased significantly irrespective of irrigation method. The largest residual $\mathrm{NO}_{3}-\mathrm{N}$ was found in FIFND treatment, followed by FIFNS treatment, and the smallest in AIAN and AICN treatments (Table 3).

In 2014 (Table 3), for each individual soil layer as well as $0-100 \mathrm{~cm}$ soil profile, for both $\mathrm{AI}$ and $\mathrm{CI}$, residual $\mathrm{NO}_{3}-\mathrm{N}$ had no response to $\mathrm{N}$ supply method. On the contrary, compared to $\mathrm{CI}$, residual $\mathrm{NO}_{3}-\mathrm{N}$ was significantly decreased by AI in either $\mathrm{N}$ supply method (excluded in 40-60 cm). These results indicated that alternate furrow irrigation coupled with conventional or alternate $\mathrm{N}$ supply was useful to reduce residual $\mathrm{NO}_{3}-\mathrm{N}$ in $0-100 \mathrm{~cm}$ soil profile at maturity. 
Table 3. Soil residual $\mathrm{NO}_{3}-\mathrm{N}\left(\mathrm{kg} \mathrm{ha}^{-1}\right)$ in $0-100 \mathrm{~cm}$ soil profile at maturity $\left(\mathrm{R}_{6}\right)$ in 2012 and 2014

\begin{tabular}{llllllll}
\hline \multirow{2}{*}{ Year } & \multirow{2}{*}{ Treatment } & \multicolumn{5}{c}{ Soil depth $(\mathrm{cm})$} \\
\cline { 3 - 7 } & & $0-20$ & $20-40$ & $40-60$ & $60-80$ & $80-100$ & $0-100$ \\
\hline 2012 & AIAN & $29.2 \pm 2.1 \mathrm{c}$ & $28.4 \pm 1.8 \mathrm{c}$ & $15.6 \pm 0.7 \mathrm{~b}$ & $12.1 \pm 0.6 \mathrm{~b}$ & $10.1 \pm 0.3 \mathrm{~b}$ & $95.3 \pm 2.9 \mathrm{e}$ \\
& AICN & $28.6 \pm 2.2 \mathrm{c}$ & $27.2 \pm 2.1 \mathrm{c}$ & $14.8 \pm 1.3 \mathrm{~b}$ & $11.3 \pm 0.8 \mathrm{~b}$ & $9.7 \pm 0.5 \mathrm{~b}$ & $91.5 \pm 3.4 \mathrm{e}$ \\
& AIFN & $31.3 \pm 3.4 \mathrm{~b}$ & $30.6 \pm 2.7 \mathrm{~b}$ & $16.6 \pm 1.1 \mathrm{~b}$ & $13.5 \pm 1.0 \mathrm{~b}$ & $11.7 \pm 0.8 \mathrm{~b}$ & $103.8 \pm 4.8 \mathrm{~d}$ \\
& CIAN & $31.3 \pm 2.8 \mathrm{~b}$ & $30.9 \pm 2.8 \mathrm{~b}$ & $15.5 \pm 1.0 \mathrm{~b}$ & $12.8 \pm 1.3 \mathrm{~b}$ & $11.7 \pm 0.8 \mathrm{~b}$ & $103.1 \pm 4.2 \mathrm{~d}$ \\
& CICN & $30.7 \pm 2.7 \mathrm{~b}$ & $30.5 \pm 3.0 \mathrm{~b}$ & $16.6 \pm 0.9 \mathrm{~b}$ & $12.9 \pm 0.7 \mathrm{~b}$ & $11.5 \pm 0.4 \mathrm{~b}$ & $102.2 \pm 2.4 \mathrm{~d}$ \\
& CIFN & $34.6 \pm 3.6 \mathrm{ab}$ & $33.1 \pm 3.5 \mathrm{~b}$ & $18.5 \pm 1.4 \mathrm{a}$ & $14.9 \pm 1.2 \mathrm{a}$ & $11.3 \pm 0.9 \mathrm{~b}$ & $112.4 \pm 3.5 \mathrm{c}$ \\
& FIAN & $32.7 \pm 3.8 \mathrm{~b}$ & $31.5 \pm 2.8 \mathrm{~b}$ & $16.2 \pm 1.1 \mathrm{~b}$ & $15.5 \pm 1.8 \mathrm{a}$ & $11.3 \pm 0.8 \mathrm{~b}$ & $107.2 \pm 3.4 \mathrm{~cd}$ \\
& FICN & $32.6 \pm 3.5 \mathrm{~b}$ & $31.6 \pm 1.8 \mathrm{~b}$ & $14.6 \pm 0.8 \mathrm{~b}$ & $15.0 \pm 0.5 \mathrm{a}$ & $12.5 \pm 1.0 \mathrm{~b}$ & $106.3 \pm 4.5 \mathrm{~cd}$ \\
& FIFNS & $34.8 \pm 4.1 \mathrm{ab}$ & $32.5 \pm 3.2 \mathrm{~b}$ & $18.9 \pm 1.3 \mathrm{a}$ & $16.6 \pm 1.3 \mathrm{a}$ & $13.7 \pm 1.3 \mathrm{a}$ & $116.5 \pm 4.8 \mathrm{~b}$ \\
& FIFND & $44.5 \pm 4.8 \mathrm{a}$ & $42.8 \pm 4.4 \mathrm{a}$ & $14.6 \pm 0.7 \mathrm{~b}$ & $10.6 \pm 0.9 \mathrm{c}$ & $9.8 \pm 0.4 \mathrm{~b}$ & $123.3 \pm 6.1 \mathrm{a}$ \\
\hline 2014 & AIAN & $23.2 \pm 2.3 \mathrm{~b}$ & $21.4 \pm 1.5 \mathrm{~b}$ & $12.4 \pm 0.7 \mathrm{a}$ & $10.0 \pm 0.5 \mathrm{~b}$ & $8.5 \pm 0.3 \mathrm{~b}$ & $75.5 \pm 3.5 \mathrm{~b}$ \\
& AICN & $22.6 \pm 1.8 \mathrm{~b}$ & $20.2 \pm 2.7 \mathrm{~b}$ & $11.5 \pm 0.5 \mathrm{a}$ & $9.6 \pm 0.6 \mathrm{~b}$ & $8.6 \pm 0.8 \mathrm{~b}$ & $73.5 \pm 4.1 \mathrm{~b}$ \\
& CIAN & $25.4 \pm 2.2 \mathrm{a}$ & $23.4 \pm 1.5 \mathrm{a}$ & $12.8 \pm 1.1 \mathrm{a}$ & $11.3 \pm 0.5 \mathrm{a}$ & $10.1 \pm 0.4 \mathrm{a}$ & $83.0 \pm 5.0 \mathrm{a}$ \\
& CICN & $27.8 \pm 3.0 \mathrm{a}$ & $22.5 \pm 2.1 \mathrm{a}$ & $13.4 \pm 0.8 \mathrm{a}$ & $11.8 \pm 0.6 \mathrm{a}$ & $10.5 \pm 0.6 \mathrm{a}$ & $86.0 \pm 4.7 \mathrm{a}$ \\
\hline
\end{tabular}

Note. Values are means \pm standard error $(\mathrm{n}=3)$. Different letters in the same column within same year indicate significant difference $(P<0.05)$.

\section{Discussion}

Dynamics of $\mathrm{NO}_{3}-\mathrm{N}$ concentration in soil profile displayed a type of ' $\mathrm{M}$ ' during the growing season, with two peak points at 6 collars and tasseling of maize stage, respectively. In addition, the decrease of $\mathrm{NO}_{3}-\mathrm{N}$ concentration from 6 collars to 12 collars was slight but sharp from tasseling to filling (Figures 4 and 5).This was obviously related to the changes of $\mathrm{N}$ application and crop $\mathrm{N}$ requirement. The first soil sampling was earlier than the first $\mathrm{N}$ application while all of them were ahead of the sowing, resulting in the lowest and first peak point of $\mathrm{NO}_{3}-\mathrm{N}$ concentration at the beginning of the growing season and at 6 collars, respectively. Crop $\mathrm{N}$ uptake increased gradually with maize growth going, leading soil $\mathrm{NO}_{3}-\mathrm{N}$ decreasing from 6 collars. Soil $\mathrm{NO}_{3}-\mathrm{N}$ reached its second peak point at tasseling after the second $\mathrm{N}$ application at 12 collars. Though $25 \%$ of $200 \mathrm{~kg} \mathrm{~N}$ $\mathrm{ha}^{-1}$ has been supplied at tasseling, from tasseling to filling when maize plant was in its reproductive period, the N demand was dramatically increased (Hirel, Gouis, Ney, \& Gallais, 2007) and much more than that from 6 collars to 12 collars (Chikowo, Mapfumo, Nyamugafata, Nynamadzawo, \& Giller, 2003), resulting in a sharp decrease of $\mathrm{NO}_{3}-\mathrm{N}$ concentration from tasseling.

However, an enhanced decrease of $\mathrm{NO}_{3}-\mathrm{N}$ concentration from tasseling to filling was observed for south of the plant (SP) of AICN treatment and north of the plant (NP) of FIFND treatment in 40-60 cm soil profile (Figure 4d, f). For AICN treatment, on one side, AI could enhance root growth compared to CI (Liang, Zhang, \& Wang, 1996; Mingo, Theobald, Bacon, Davis, \& Dodd, 2004), and the effect was amplified by its coupling with CN (Qi, $\mathrm{Hu}, \mathrm{Wu}, \& \mathrm{Niu}, 2015)$. When crop $\mathrm{N}$ requirement was increased from tasseling to filling (Hirel et al., 2007), N supply from $0-40 \mathrm{~cm}$ may not be enough, thus stimulating the relatively developed roots under AICN (Qi, Hu, $\mathrm{Wu}, \& \mathrm{Niu}, 2015)$ to enhance the $\mathrm{N}$ absorption from $40-60 \mathrm{~cm}$. On the other side, $\mathrm{NO}_{3}-\mathrm{N}$ in $40-60 \mathrm{~cm}$ could move upward as a function of mass flow due to more consumption of $\mathrm{NO}_{3}-\mathrm{N}$ in $0-40 \mathrm{~cm}$ (Song \& $\mathrm{Li}, 2005$ ). In addition, the irrigated position for AI was located in SP at tasseling and the relatively adequate water supply might enhance depletion of $\mathrm{NO}_{3}-\mathrm{N}$ at $\mathrm{SP}$ ( $\mathrm{Li}$ et al., 2009). For FIFND treatment, root growth at $\mathrm{NP}$ (the $\mathrm{N}$ fertilizer supplied side) in 0-40 cm may be inhibited because of high $\mathrm{N}$ concentration (Tian, Chen, \& Liu, 2008), which might induce more roots to extend to deeper soil layers. Thus, $\mathrm{NO}_{3}-\mathrm{N}$ in $40-60 \mathrm{~cm}$ under $\mathrm{NP}$ might become an ideal $\mathrm{N}$ source for absorption when plants are in dire need of $\mathrm{N}$ nutrition. This compares well with the findings that the enhanced decrease of $\mathrm{NO}_{3}-\mathrm{N}$ in local area was closely related to the improved root growth (Wang, de Kroon, \& Smits, 2007). These suggested that dynamics of soil $\mathrm{NO}_{3}-\mathrm{N}$ were related to the supply of $\mathrm{N}$ and water, crop $\mathrm{N}$ requirement and the root growth.

In comparison to $\mathrm{CI}$, residual $\mathrm{NO}_{3}-\mathrm{N}$ in $0-100 \mathrm{~cm}$ soil profile was significantly reduced by AI under three $\mathrm{N}$ supply methods (Table 3). This was sustained by the results that AI plants absorbed more N than CI (data not shown). These results are in line with the conclusion that AI irrigation practice had better $\mathrm{N}$-fertilizer recovery 
with minimal mineral $\mathrm{N}$ left in the soil for maize (Kirda et al., 2005) and potato (Shahnazari et al., 2008). Shahnazari et al. (2008) suggested that reduced residual $\mathrm{NO}_{3}-\mathrm{N}$ under $\mathrm{AI}$ can be ascribed to both enhanced $\mathrm{N}$ uptake by the plants and increased $\mathrm{N}$ losses to the air via denitrification. However, contrary results for residual $\mathrm{NO}_{3}-\mathrm{N}$ were reported by Tan et al. (2005) and Liu et al. (2011). They insisted that compared to CI, leaching of $\mathrm{NO}_{3}-\mathrm{N}$ was reduced due to lateral flow increased by AI (Pan \& Kang, 2000; Zhou et al., 2008). As a result, increased residual $\mathrm{NO}_{3}-\mathrm{N}$ was found in $\mathrm{AI}$ rather than $\mathrm{CI}$. Differences in $\mathrm{N}$ fertilizer rate, irrigation volume, climate condition, soil water characteristic and their interaction might contribute to the difference. Indeed, this needs to be further investigated.

Obvious concentration of soil $\mathrm{NO}_{3}-\mathrm{N}$ was observed in the $\mathrm{N}$ applied side for both FIFND and FIFNS treatments, and the difference was that the concentration was higher in FIFND and deeper in FIFNS (Figures $2 \mathrm{i}$ and $2 \mathrm{j}$ ). This could be explained as follows: For FIFND treatment in which $\mathrm{N}$ fertilizer was supplied with separation from water, as soil moisture content determines the soil $\mathrm{N}$ availability and its transport to the roots $\mathrm{Hu}, \mathrm{Li}$, \& Zhang, 2009), $\mathrm{N}$ absorption from the non-irrigated side of FI might be reduced by severe water deficit. For FIFNS treatment in which $\mathrm{N}$ fertilizer was supplied with irrigation water, soil water moved mainly in vertical direction under FI (Data not shown), which brought about downward movement of $\mathrm{NO}_{3}-\mathrm{N}$ thus being far from the root system. Moreover, residual $\mathrm{NO}_{3}-\mathrm{N}$ of both FIFND and FIFNS at maturity was higher than that of the other treatments (Table 3). Skinner et al. (1999) demonstrated that the prerequisite for FI to increase N uptake and reduce residual $\mathrm{NO}_{3}-\mathrm{N}$ was a climate condition that allowed adequate root development within its non-irrigated furrow. However, this experimental area is prone to large evapotranspiration (about $2000 \mathrm{~mm}$ in average), and received only $129 \mathrm{~mm}$ of precipitation during the maize growing season in 2012 (Figure 1). Meanwhile, our previous work showed that FI obviously reduced maize root growth in the same area (Qi et al., 2015). Moreover, $\mathrm{N}$ uptake by FIFND and FIFNS plants was significantly decreased compared to the other treatments (data not shown). Thus, neither FIFND nor FIFNS ought to be recommended for management of $\mathrm{N}$ and water in the arid area.

It cannot be ignored that $\mathrm{N}$ supply method, irrigation method and their interaction had a significant impact on $\mathrm{NO}_{3}-\mathrm{N}$ concentration in 0-40 cm soil profile in 2012 but not in 2014 (excluded irrigation method) (Table 2). This was mainly ascribed to exclude fixed treatments in 2014, where $\mathrm{NO}_{3}-\mathrm{N}$ distribution in $0-40 \mathrm{~cm}$ was comparable for $\mathrm{AI}$ or $\mathrm{CI}$ coupled with $\mathrm{CN}$ and $\mathrm{AN}$ (Figure 3). Moreover, compared to $\mathrm{CI}, \mathrm{AI}$ increased $\mathrm{NO}_{3}-\mathrm{N}$ content under the plant in $0-40 \mathrm{~cm}$ and decreased that in $40-80 \mathrm{~cm}$ for three $\mathrm{N}$ supply methods (Figures 2 and 3). This might be related to the differences in change of soil moisture between AI and CI. For AI, soil moisture content between the two parts of the root systems risen and fallen alternatively, while for $\mathrm{CI}$, the soil moisture risen/fallen meantime during 6 collars to maturity (Data not shown). Thus, AI could keep more $\mathrm{NO}_{3}-\mathrm{N}$ in the upper soil layer through stimulated lateral flow and reduced deep percolation (Pan \& Kang, 2000; Zhou, Kang, Li, \& Zhang, 2008).

\section{Conclusions}

At filling stage, under the same method of $\mathrm{N}$ supply, alternate furrow irrigation enhanced soil $\mathrm{NO}_{3}-\mathrm{N}$ concentration under the plant in $0-40 \mathrm{~cm}$ soil profile and reduced that in $40-80 \mathrm{~cm}$ thanks to its increased lateral irrigation water flow. Conventional and alternate $\mathrm{N}$ supply coupled with alternate or conventional furrow irrigation brought a relatively uniform distribution of soil $\mathrm{NO}_{3}-\mathrm{N}$ across the plant rows; while fixed $\mathrm{N}$ supply enhanced $\mathrm{NO}_{3}-\mathrm{N}$ concentration under the $\mathrm{N}$ supplied side in $0-80 \mathrm{~cm}$ soil profile for three irrigation methods. Compared to conventional furrow irrigation, alternate furrow irrigation reduced soil $\mathrm{NO}_{3}-\mathrm{N}$ concentration in $60-100 \mathrm{~cm}$ soil profile from 12 collars to maturity when coupled with alternate or conventional $\mathrm{N}$ supply, resulting in decreased soil residual $\mathrm{NO}_{3}-\mathrm{N}$ in $0-100 \mathrm{~cm}$. This might be related to reduce downward movement of $\mathrm{NO}_{3}-\mathrm{N}$ and enhanced $\mathrm{N}$ uptake by plant under alternate furrow irrigation. Therefore, spatial distribution of soil $\mathrm{NO}_{3}-\mathrm{N}$ during maize season was optimum and soil residual $\mathrm{NO}_{3}-\mathrm{N}$ was minimal at maturity under alternate furrow irrigation as long as conventional or alternate $\mathrm{N}$ supply method are used.

\section{References}

Bao, S. (2000). Soil and agricultural chemistry analysis. Edition III, Beijing: Chinese Agriculture Press.

Bar-Yosef, B., \& Sheikholslami, M. R. (1976). Distribution of water and ions in soils irrigated and fertilized from a trickle source. Soil Science Society of American Journal, 40, 575-582. http://dx.doi.org/10.2136/ sssaj1976.03615995004000040033x

Benjamin, J. G., Havis, H. R., Ahuja, L. R., \& Alonso, C. V. (1994). Leaching and water flow patterns in every-furrow irrigation. Soil Science Society of American Journal, 58, 1511-1517. http://dx.doi.org/10.2136/ sssaj1994.03615995005800050034x 
Benjamin, J. G., Porter, L. K., Duke, H. R., \& Alonso, C. V. (1997). Corn growth and nitrogen uptake with furrow irrigation and fertilizer bands. Agronomy Journal, 89, 609-612. http://dx.doi.org/10.2134/agronj1997. $00021962008900040012 x$

Chikowo, R., Mapfumo, P., Nyamugafata, P., Nynamadzawo, G., \& Giller, K. E. (2003). Nitrate-N dynamics following improved fallows and maize root development in a Zimbawean sandy clay loam. Agroforestry Systems, 59, 187-195. http://dx.doi.org/10.1023/B:AGFO.0000005219.07409.a0

Emteryd, O. (1989). Chemical and physical analysis of inorganic nutrients in plant, soil, water and air. Sweden: Stencil No 10 Umea.

Gheysari, M., Mirlatifi, M. S., Homaee, M., Asadi, E. M., \& Hoogenboom, G. (2009). Nitrate leaching in a silage field under different irrigation and nitrogen fertilizer rates. Agricultural Water Management, 96, 946-954. http://dx.doi.org/10.1016/j.agwat.2009.01.005

Han, K., Yang, Y., Zhou, C., Shangguan Y., Zhang, L., Li, N., \& Wang, L. (2014). Management of furrow irrigation and nitrogen application on summer maize. Agronomy Journal, 106(4), 1402-1410. http://dx.doi.org/10.2134/agronj13.0367

Hirel, B., Gouis, J. L., Ney, B., \& Gallais, A. (2007). The challenge of improving nitrogen use efficiency in crop plants: Towards a more central role for genetic variability and quantitative genetics within integrated approaches. Journal of Experimental Botany, 58, 2369-2387. http://dx.doi.org/10.1093/jxb/erm097

Hu, T., Kang, S., Li, F., \& Zhang, J. (2009). Effects of partial root-zone irrigation on the nitrogen absorption and utilization of maize. Agricultural Water Management, 96, 208-214. http://dx.doi.org/10.1016/j.agwat.2008. 07.011

Ju, X., Liu, X., Zhang, F., \& Roelcke, M. (2004). Nitrogen fertilization, soil nitrate accumulation and policy recommendations in several agricultural regions of China. American Biology Teachnology, 33, 278-283. http://dx.doi.org/10.1579/0044-7447-33.6.300

Kang, S., Liang, Z., Hu, W., \& Zhang, J. (1998). Water use efficiency of controlled alternate irrigation on root-divided maize plants. Agricultural Water Management, 38, 69-76. http://dx.doi.org/10.1016/S03783774(98)00048-1

Kang, S., Zhang, J., Liang, Z., Hu, X., \& Cai, H. (1997). The controlled alternative irrigation - A new approach for water saving regulation in farmland. Agricultural Research Arid Area, 15(1), 1-6.

Kirda, C., Topcu, S., Kaman, H., Ulger, A. C., Yazici, A., Cetin, M., \& Derici, M. R. (2005). Grain yield response and N-fertilizer recovery of maize under deficit irrigation. Field Crops Research, 93, 132-141. http://dx.doi.org/10.1016/j.fcr.2004.09.015

Li, J., Zhang, J., \& Ren, L. (2003). Water and nitrogen distribution as affected by fertigation of ammonium nitrate from a point source. Irrigation Science, 22, 19-30. http://dx.doi.org/10.1007/s00271-003-0064-8

Liang, J., Zhang, J., \& Wong, M. H. (1996). Effects of air-filled soil porosity and aeration on the initiation and growth of secondary roots of maize (Zea mays). Plant Soil, 186, 245-254. http://dx.doi.org/10.1007/ BF02415520

Liu, X., Zhang, F., Yang, Q., Wang, J., \& Li, Z. (2011). Transfer of mineral nitrogen in maize root zone soil under different irrigation methods. Chinese Journal of Eco-Agriculture, 19, 540-547. http://dx.doi.org/ 10.3724/SP.J.1011.2011.00540

Liu, Y., Li, Y., Pan, T., Qu, L., \& Du, Z. (2009). Study on effects of different irrigation treatments on evapotranspiration and yield in spring maize. Arid Research in Arid Area, 27, 67-72.

Mingo, D. M., Theobald, J. C., Bacon, M. A., Davies, W. J., \& Dodd, I. C. (2004). Biomass allocation in tomato (Lycopersicon esculentum) plants grown under partial root-zone drying: enhancement of root growth. Function Plant Biology, 31, 971-978. http://dx.doi.org/10.1071/FP04020

Morison, J. I. L., Baker, N. R., Mullineaux, P. M., \& Davies, W. J. (2008). Improving water use in crop production. Philosiphical Transactions of the Royal Society, 363, 639-658. http://dx.doi.org/10.1098/ rstb.2007.2175

Pan, Y., \& Kang, S. (2000): Irrigation water infiltration in furrows and crop water use of alternate furrow irrigation. Transactions CASE, 16, 39-43. 
Qi, D., Hu, T., Wu, X., \& Niu, X. (2015). Rational irrigation and nitrogen supply methods improving root growth and yield of maize. Transactions CASE, 31, 144-149.

Ritchie, S. W., \& Hanway, J. J. (1982). How a corn plant develops. Special Report 48. Review Iowa State University Cooperation Extensive Service, American, IA.

Shahnazari, A., Ahmadi, S. H., Laerke, P. E., Liu, F. L., Plauborg, F., Jacobsen, S. E., ... Andersen, M. N. (2008). Nitrogen dynamics in the soil plant system under deficit and partial root-zone drying irrigation strategies in potatoes. European Journal of Agronomy, 28, 65-73. http://dx.doi.org/10.1016/j.eja.2007.05.003

Shahnazari, A., Liu, F., Andersen, M. N., Jacobsen, S., \& Jensen, R. C. (2007). Effects of partial root-zone drying on yield, tuber size and water use efficiency in potato under field conditions. Field Crops Research, 100, 117-124. http://dx.doi.org/10.1016/j.fcr.2006.05.010

Singandhupe, R. B., Rao, G. G. S. N., Patil, N. G., \& Brahmanand, P. S. (2003). Fertigation studies and irrigation scheduling in drip irrigation system in tomato crop (Lycopersicum esculentum L.). European Journal of Agronomy, 19, 327-340. http://dx.doi.org/10.1016/S1161-0301(02)00077-1

Skinner, R. H., Hanson, J. D., \& Benjamin, J. G. (1999). Nitrogen uptake and partitioning under alternate and every furrow irrigation. Plant Soil, 210, 11-20. http://dx.doi.org/10.1023/A:1004695301778

Song, H., \& Li, S. (2005). Effects of root uptake function and soil water on $\mathrm{NO}_{3}^{-}-\mathrm{N}$ and $\mathrm{NO}_{4}{ }^{+}-\mathrm{N}$ distribution. Scientia Agricultural Science, 38, 96-101.

Tafteh, A., \& Sepaskhah. (2012). Yield and nitrogen in maize field under different nitrogen rates and partial root drying irrigation. International Journal of Plant Production, 6, 94-113. Retrieved from http://ijpp.gau.ac.ir/ article_672_101.html

Tan, J., Wang, L., \& Li, S. (2005). Movement and utilization of water and nutrient under different irrigation patterns. Plant Nutrition Fertilizer Society, 11, 442-448.

Tang, L., Li, Y., \& Zhang, J. (2010). Partial root zone irrigation increase water use efficiency, maintains yield and enhance economic profit of cotton in arid area. Agricultural Water Management, 97, 1527-1533. http://dx.doi.org/10.1016/j.agwat.2010.05.006

Tarkalson, D. D., Payero, J. O., Ensley, S. M., \& Shapiro, C. A. (2006). Nitrogen accumulation and movement under deficit irrigation in soil receiving cattle manure and commercial fertilizer. Agricultural Water Management, 85, 201-210. http://dx.doi.org/10.1016/j.agwat.2006.04.005

Tian, Q., Chen, F., \& Liu, J. (2008). Inhibition of maize root growth by high nitrate supply is correlated with reduced IAA levels in roots. Journal of Plant Physiology, 165, 942-951. http://dx.doi.org/10.1016/ j.jplph.2007.02.011

Tsai, C. Y., Huber, D. M., Glover, D. V., \& Warren, H. L. (1984). Relationship of N deposition to grain yield and N responses of three maize hybrids. Crop Science, 24, 277-281. http://dx.doi.org/10.2135/cropsci1984.001 1183X002400020016x

Wang, C., Zhu, P., Shu, L., Zhu, J., Yu, H., Zhan, Y., \& Yuan, M. (2014). Effects of alternate partial root irrigation and nitrogen forms on utilization and movement of nitrate in soil. Transactions CASE, 30, 92-101.

Wang, L., de Kroon, H., \& Smits, A. J. M. (2007). Combined effects of partial root zone drying and patchy fertilizer placement on nutrient acquisition and growth of oilseed. Plant Soil, 295, 207-216. http://dx.doi.org/10.1007/s11104-007-9276-7

Wang, Q., Li, F., Zhang, E., Li, G., \& Vance, M. (2012). The effects of irrigation and nitrogen application rates on yield of spring wheat (longfu-920), and water use efficiency and nitrate nitrogen accumulation in soil. Australian Journal of Crop Science, 6, 662-672. Retrieved from http://search.informit.com.au/document Summary; $\mathrm{dn}=362475432090775$;res $=$ IELHSS

Xing, W., Wang, L., Li, L., \& Li, S. (2003). Effect of water-fertilized spatial coupling on corn in semiarid area $\prod$ dynamics distribution of water and available nitrogen in soil. Soil, 35, 242-247.

Yang, R., \& Su, Y. (2009). Effects of nitrogen fertilization and irrigation rate on grain yield, nitrate accumulation and nitrogen balance on sandy farmland in the marginal oasis in the middle of Heihe River basin. Acta Ecology Sinica, 28, 1460-1469.

Zhang, L., Ma, Z., \& E, S. (2007). Effects of ridge cultivation with plastic film Mulching furrow irrigation on yield and water use efficiency of seed corn. Acta Agricultural Since, 16, 83-86. 
Zhou, Q., Kang, S., Li, F., \& Zhang, L. (2008). Comparison of dynamic and static APRI-models to simulate soil water dynamics in a vineyard over the growing season under alternate partial root-zone drip irrigation. Agricultural Water Management, 95, 767-775. http://dx.doi.org/10.1016/j.agwat.2008.01.018

Zhu, P., Wu, S., Shu, L., Liu, F., Zhu, K., \& Guo, J. (2013). Coupling effects of water and nitrogen application with partial root zone irrigation on growth of cucumber and nitrate distribution in soil. Bulletin Soil Water Conversation, 33, 6-16.

Zotarelli, L., Dukes, M. D., Scholberg, M. S. J., Munoz-Carpena, R., \& Icerman, J. (2009). Tomato nitrogen accumulation and fertilizer use efficiency on a sandy soil, as affected by nitrate rate and irrigation scheduling. Agricultural Water Management, 96, 1247-1258. http://dx.doi.org/10.1016/j.agwat.2008.06.007

\begin{abstract}
Abbreviations
$\mathrm{AI}$, alternate furrow irrigation; FI, fixed furrow irrigation; CI, conventional furrow irrigation; AN, alternate nitrogen supply; FN, fixed nitrogen supply; CN, conventional nitrogen supply; UP, under the plant; SP, south of the plant; NP, north of the plant; $\mathrm{V}_{6}, \mathrm{~V}_{12}, \mathrm{VT}, \mathrm{R}_{2}$ and $\mathrm{R}_{6}$ represents 6 collars, 12 collars, tasseling, filling and maturity of maize development stage, respectively.
\end{abstract}

\title{
Copyrights
}

Copyright for this article is retained by the author(s), with first publication rights granted to the journal.

This is an open-access article distributed under the terms and conditions of the Creative Commons Attribution license (http://creativecommons.org/licenses/by/4.0/). 